\title{
Decreases in human immunodeficiency virus infection rates in Kombolcha, Ethiopia: a 10-year data review
}

This article was published in the following Dove Press journal:

HIVIAIDS - Research and Palliative Care

7 July 2016

Number of times this article has been viewed

\author{
Melashu Balew Shiferaw' \\ Gebremedhin Berhe \\ Gebregergs ${ }^{2}$ \\ Mulusew Alemneh Sinishaw ${ }^{3}$ \\ Yohannes Amede Yesuf ${ }^{4}$ \\ 'Laboratory Capacity Building \\ Core Process, Bahir Dar Regional \\ Health Research Laboratory Center, \\ Bahir Dar, Ethiopia; ${ }^{2}$ Department \\ of Epidemiology, College of Health \\ Sciences, School of Public Health, \\ Mekelle University, Mekelle, Ethiopia; \\ ${ }^{3}$ Department of Clinical Chemistry, \\ Bahir Dar Regional Health Research \\ Laboratory Center, Bahir Dar, \\ Ethiopia; ${ }^{4}$ Department of Laboratory, \\ Africa Service Committee Clinic, \\ Kombolcha, Ethiopia
}

Correspondence: Melashu Balew Shiferaw

Bahir Dar Regional Health Research

Laboratory Center, P.O. Box 64I,

Bahir Dar, Ethiopia

Tel +25I 58928496357

Email bmelashu@gmail.com
Introduction: Acquired immunodeficiency syndrome is one of the most serious public health and development challenges in sub-Saharan Africa, including Ethiopia. A particular challenge for prevention strategies has been the emergence of hotspot areas. Therefore, human immunodeficiency virus (HIV)/acquired immunodeficiency syndrome programs should not be based on national level statistics, but need to be more focused geographically. Kombolcha is one of the high spot areas with different projects and development corridors. Hence, the aim of this study is to assess the trend of HIV infection rates among patients who visited Africa Service Committee clinic from 2005 to 2014. Methods: An institutional-based cross-sectional study was conducted from January 1 to January 30, 2016. All records of new patients enrolled from February 8, 2005 to December 31, 2014 were reviewed. Data on sociodemographic information, risky sexual behavior, and HIV test result were collected from each study participant using data collection format. Data were analyzed using SPSS version 20.0. A multivariate logistic regression model was used to identify risk factors of HIV infection.

Results: The overall HIV infection was $10.8 \%(2,233 / 20,674)$. The rate of infection varied from $13.3 \%$ in 2005 to $4.5 \%$ in 2014 , and its trend had significantly declined from 2008 to 2014 . Urban residence (adjusted odds ratio [AOR]: 2.53; 95\% confidence interval [CI]: 1.22-5.25), patients who ever had intercourse with penetration (AOR: 5.62; 95\% CI: 1.11-28.57), and those who had marriage experience (AOR: 11.65; 95\% CI: 4.2-32.3) were more infected with HIV. Conclusion: The trend of HIV infection significantly reduced in the last 10 years in Kombolcha area. However, the HIV infection still remains high (4.5\%) that needs intervention of those who had marriage experience, risky sexual behavior, and urban dwellers.

Keywords: HIV, infection, Kombolcha, Ethiopia

\section{Introduction}

Human immunodeficiency virus (HIV) is one of the most serious public health and development challenge in sub-Saharan Africa. HIV-1 subtype C, which mainly spreads through unprotected heterosexual intercourse, remains the predominant strain in Ethiopia. ${ }^{1}$

In Ethiopia, the estimated number of people living with HIV was 769,602 with 15,614 new HIV infections and 35,578 acquired immunodeficiency syndrome (AIDS)related deaths in $2014 .{ }^{2}$ Moreover, the estimated national adult HIV incidence of $0.28 \%$ in 2009 translates to over 131,000 new HIV infections with urban HIV incidence ranging from $0.56 \%$ in Somali to $3.5 \%$ in Afar regions. ${ }^{3}$

The HIV epidemic may be less severe, less generalized, and more heterogeneous than previously believed. It seems to have stabilized or even declined in most of the 
major urban centers, while increasing in the smaller towns. ${ }^{4}$ A particular challenge for prevention strategies has been the emergence of hotspots as an unintended by-product of accelerated development schemes. These hotspots attract mobile groups, money, and opportunities for sex trade: the key ingredients known to foster epidemic spread. Mapping prevention activities and documentation of behavioral outcomes remain core activities for a responsive most at risk population HIV prevention programming at regional and district levels. ${ }^{5}$

The strategic plan for intensifying multisectorial HIV and AIDS response II in Ethiopia identifies female sex workers, uniformed forces, long distance drivers, never-married sexually active females, discordant couples, migrant laborers, migrant groups (especially those in small towns), cross border populations, and in-school youth (particularly at tertiary education) as most at risk populations for HIV infection. ${ }^{5,6}$

For effective prevention, HIV/AIDS programs should not be based on national level statistics, but rather need to be more focused geographically and directed to those regions, districts, or communities exhibiting higher prevalence rates. ${ }^{4}$ Small towns are becoming hotspots and can potentially bridge further spread of HIV epidemic to rural settings. ${ }^{3}$ Kombolcha is one of the small towns assumed to be a hotspot. ${ }^{2}$ Therefore, the aim of this study was to assess the trend of HIV infection rate in the proposed setting in the last 10 years.

\section{Methods}

\section{Setting and study population}

An institutional-based cross-sectional study was conducted from January 1 to January 30, 2016 among patients who visited (self-referred to) Africa Service Committee clinic (Nongovernmental Organization): Voluntary HIV Counseling and Testing center. The clinic was opened by Africa Service Committee Ethiopia at Kombolcha town, Northeast Ethiopia, on January 1, 2005. Kombolcha is located $\sim 382 \mathrm{~km}$ away from Addis Ababa, the capital city of Ethiopia. According to the 2007 census, Kombolcha district has a population of 85,367 , of whom 41,968 were male, and $68.7 \%$ were urban dwellers. ${ }^{7}$ All records of new patients with complete information (from February 8, 2005 to December 31, 2014) were reviewed. The records of patients with incomplete information were excluded. Those patient records with retesting information were also excluded to control duplication of single data.

\section{Data collection instruments and procedure}

Data on sociodemographic information, risky sexual behavior, and HIV test results of study participants were collected using a structured data collection format. Data were collected by a nurse who had previous experience on data collection and working in a voluntary counseling and testing program.

In Africa Service Committee clinic, HIV testing was carried out using serial test algorithm: KHB (Shanghai Kehua Bio-Engineering Sarl, Shanghai, People's Republic of China) as screening, STATPACK (Chembio Diagnostic Systems, Inc., Medford, NY, USA) as confirmatory, and Uni-gold (Trinity Biotech Plc, Bray, Ireland) as tie-breaker testing kits.

\section{Data management and analysis}

Data were checked, coded, entered, and analyzed by SPSS version 20.0 (IBM Corporation, Armonk, NY, USA). Risk factors were determined only for the recent year (2014) by considering its significance for intervention. Selected variables with a $P$-value $<0.2$ were fitted to the bivariate logistic regression and further entered into multivariate logistic regression model. Backward logistic regression method was employed. Variables having a $P$-value $<0.05$ were taken as significant. Crude and adjusted odds ratios (AORs) with $95 \%$ confidence intervals (CIs) were calculated.

\section{Ethical considerations}

Ethical clearance was obtained from the ethical review committee of Amhara Regional Health Bureau. A official permission letter was obtained from the Amhara Regional Health Bureau and Africa Service Committee clinic, Kombolcha branch office. As we used secondary data, informed consent from individual patients was not possible. Names and medical registration numbers of patients were not included in this study.

\section{Results}

\section{Sociodemographic characteristics}

A total of 20,674 patient's records were reviewed. The median age of the patients was 22 with a range of $12-70$ years. More than half $(54.1 \%)$ of the participants were males. Urban residents were $12,361(59.8 \%)$. Regarding marital status, $13,981(67.6 \%)$ participants were never married. The majority of the patients, $12,733(61.6 \%)$, earned less than a hundred Ethiopian Birr per month (Table 1).

\section{Risky sexual behavior of participants}

Of the total study participants, 3,742 (18.1\%) reported use of alcohol/drugs/Khat. More than half of the participants, 10,801 (52.2\%), ever had intercourse with penetration. Regarding respondents' perception, 1,939 (9.4\%) participants did not believe condom to prevent HIV/sexually transmitted 
Table I Sociodemographic characteristics of patients at Africa Service Committee clinic, North East Ethiopia, 2005-2014

\begin{tabular}{|c|c|c|c|}
\hline Characteristics & Category & Frequency & Percent \\
\hline \multirow[t]{2}{*}{ Sex } & Male & 11,191 & 54.1 \\
\hline & Female & 9,483 & 45.9 \\
\hline \multirow[t]{8}{*}{ Age in years } & $<19$ & 6,245 & 30.2 \\
\hline & $20-24$ & 6,475 & 31.3 \\
\hline & $25-29$ & 3,786 & 18.3 \\
\hline & $30-34$ & $\mathrm{I}, 547$ & 7.5 \\
\hline & $35-39$ & 1,072 & 5.2 \\
\hline & $40-44$ & 551 & 2.7 \\
\hline & $45-49$ & 385 & 1.9 \\
\hline & $50+$ & 613 & 3.0 \\
\hline \multirow[t]{2}{*}{ Residence } & Urban & $|2,36|$ & 59.8 \\
\hline & Rural & 8,313 & 40.2 \\
\hline \multirow[t]{4}{*}{ Marital status } & Married & 2,830 & 13.7 \\
\hline & Never married & $|3,98|$ & 67.6 \\
\hline & Divorced & 3,297 & 15.9 \\
\hline & Widowed & 566 & 2.7 \\
\hline \multirow[t]{5}{*}{ Education } & Illiterate & 4,853 & 23.5 \\
\hline & Able to read & $|| 15 \mid$, & 5.6 \\
\hline & I-6 primary & 5,030 & 24.3 \\
\hline & $7-12$ secondary & 8,047 & 38.9 \\
\hline & College and above & 1,593 & 7.7 \\
\hline \multirow[t]{5}{*}{ Income per month (Birr) } & $<100$ & 12,733 & 61.6 \\
\hline & $100-500$ & 5,300 & 25.6 \\
\hline & $50 \mathrm{I}-\mathrm{I}, 000$ & 1,710 & 8.3 \\
\hline & $\mathrm{I}, 00 \mathrm{I}-2,000$ & 702 & 3.4 \\
\hline & $>2,000$ & 229 & I.I \\
\hline
\end{tabular}

infections and 1,578 (7.6\%) did not know about condom (Table 2).

\section{HIV infection and risk factors}

Of the total $(20,674)$ new participants who tested for HIV in the last 10 years (2005-2014), the overall HIV infection rate was $10.8 \%(2,233 / 20,674)$. Among the total 109 participants with symptoms of sexually transmitted infections, $84(77 \%)$ were positive for HIV. HIV infection was found in $218(25.5 \%)$ and $253(22.5 \%)$ from a total of 855 pregnant women and 1,120 commercial sex workers, respectively.

The rate of HIV infection ranged from $13.3 \%$ in 2005 to $4.5 \%$ in 2014 , and its trend had been significantly declining since $2008(P<0.05)$. The trend of infection remained high among patients aged 30 years and above (Figures 1 and 2).

HIV infection was significantly higher in urban residents (AOR: 2.53; 95\% CI: 1.22-5.25; P: 0.013). Those who had marriage experience (married, separated, divorced, and widowed) (AOR: 11.65; 95\% CI: 4.2-32.3; $P<0.001$ ) were also more infected from HIV (16.1\% among married; $21.3 \%$ among divorced; and 30.8\% among widowed) compared to never married patients $(0.9 \%)$. Moreover, patients who ever had intercourse with penetration were more vulnerable
Table 2 Risky sexual behavior of participants, Africa Service Committee clinic, Kombolcha, 2005-2014

\begin{tabular}{|c|c|c|c|}
\hline Behavior & Response & Frequency & Percent \\
\hline \multirow{2}{*}{$\begin{array}{l}\text { Did the patient use alcohol/ } \\
\text { drug/Khat? }\end{array}$} & Yes & 3,742 & 18.1 \\
\hline & No & 16,932 & 81.9 \\
\hline \multirow{2}{*}{$\begin{array}{l}\text { Did the patient ever } \\
\text { have intercourse with } \\
\text { penetration? }\end{array}$} & Yes & $|0,80|$ & 52.2 \\
\hline & No & 9,873 & 47.8 \\
\hline \multirow{5}{*}{$\begin{array}{l}\text { Did the patient use a } \\
\text { condom in the last } 3 \\
\text { months? }(\mathrm{N}=6,633)\end{array}$} & Never & 4,414 & 66.5 \\
\hline & & & \\
\hline & & & \\
\hline & Sometimes & 609 & 9.2 \\
\hline & Always & 1,610 & 24.3 \\
\hline \multirow{4}{*}{$\begin{array}{l}\text { Did the patient use a } \\
\text { condom last time to have } \\
\text { intercourse? }(\mathrm{N}=|0,13|)\end{array}$} & Yes & 3,638 & 35.9 \\
\hline & & & \\
\hline & & & \\
\hline & No & 6,493 & 64.1 \\
\hline \multirow{3}{*}{$\begin{array}{l}\text { Did the patient believe a } \\
\text { condom prevents HIV/STI? }\end{array}$} & Yes & 17,157 & 83.0 \\
\hline & No & 1,939 & 9.4 \\
\hline & Do not know & $\mathrm{I}, 578$ & 7.6 \\
\hline \multirow{2}{*}{$\begin{array}{l}\text { Is the patient a CSW? } \\
(\mathrm{N}=7,509)\end{array}$} & Yes & 1,120 & 14.9 \\
\hline & No & 6,389 & 85.1 \\
\hline \multirow{2}{*}{$\begin{array}{l}\text { Did the patient exchange } \\
\text { intercourse for material } \\
\text { assistance? }(\mathrm{N}=10,188)\end{array}$} & Yes & 1,273 & 12.5 \\
\hline & No & 8,915 & 87.5 \\
\hline
\end{tabular}

Abbreviations: CSW, commercial sex worker; HIV, human immunodeficiency virus; $\mathrm{STI}$, sexually transmitted infections.

(AOR: 5.62; 95\% CI: 1.11-28.57; P: 0.037) for HIV infection (Table 3).

\section{Discussion}

HIV infection rate is declining in Kombolcha, Ethiopia. The infection rate significantly fell from $13.3 \%$ in 2005 to $4.5 \%$ in 2014. This in line with the national data where there is a $90 \%$ reduction in HIV incidence since the introduction of President's Emergency Plan for AIDS Relief (PEPFAR) in Ethiopia in $2005 .{ }^{8}$ Despite the significant decline in the setting, the current incidence rate $(4.5 \%)$ is still unacceptable as compared to the national estimate, which is $0.04 \%$ in urban population. This difference might be attributed to the setting as Kombolcha is a geographic hotspot where most at risk populations are plentiful. ${ }^{2}$ Moreover, higher prevalence of HIV was found among pregnant women $(22.5 \%)$. This might be due to having unsafe sexual exposure to become pregnant. As part of the Prevention of Mother-to-Child Transmission (PMTCT) 


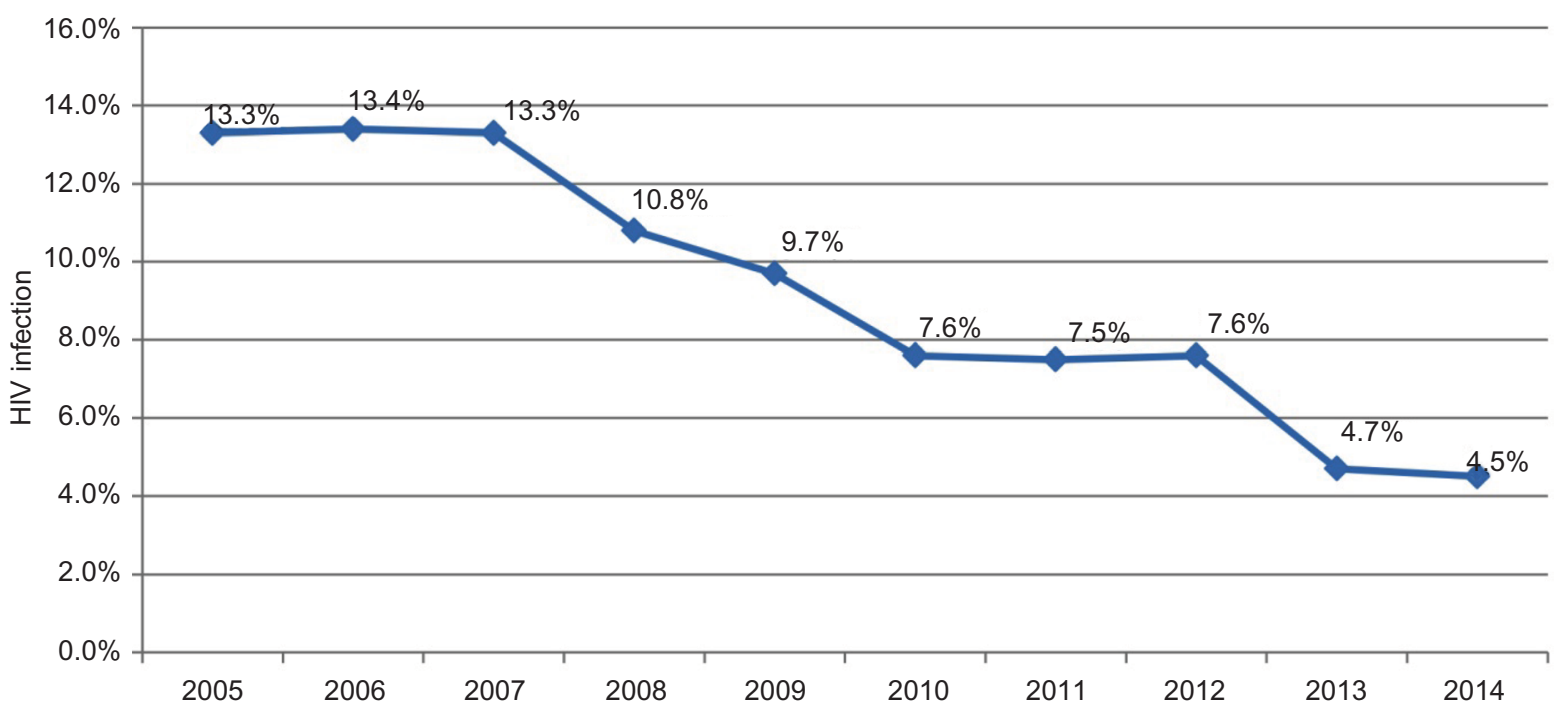

Figure I Trend of human immunodeficiency virus (HIV) infection among patients tested for HIV at Africa Service Committee clinic, Kombolcha, $2005-2014$.

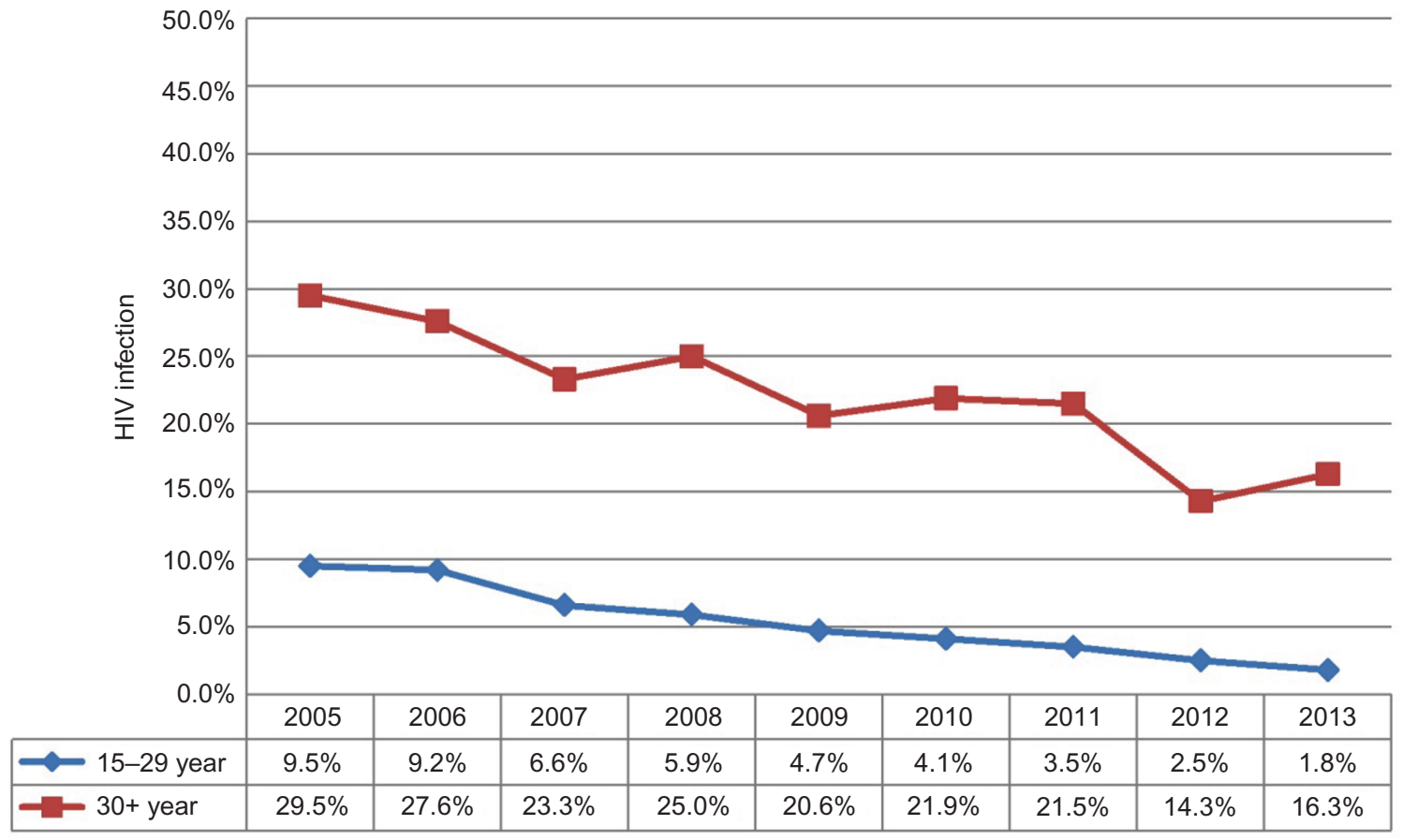

Figure 2 Trend of human immunodeficiency virus (HIV) infection with age group of patients tested for HIV at Africa Service Committee, Kombolcha, $2005-2014$.

program, the increased HIV counseling of all pregnant women by the health extension workers to get tested may also increase the probability of getting HIV-positive ones. This study has found that urban dwellers were significantly more infected than rural dwellers. This is also similarly reported from the Ethiopian demographic and health survey 2011 that showed an HIV prevalence of $4.2 \%$ in urban and $0.6 \%$ in rural. ${ }^{9}$ Moreover, antenatal statistics in sub-Saharan Africa consistently show higher HIV prevalence in urban than in rural areas. This might be due to a combination of higher levels of mobility and sexual networking than in rural communities. ${ }^{10}$
In this study, patients with at least one marriage experience had significantly higher HIV infection compared to never married patients. The Ethiopia Demographic and Health Survey (EDHS) 2011 has also shown that there is an HIV prevalence variation by marital status ( $0.3 \%$ among never married; $1.5 \%$ among married/living together; $5.2 \%$ among divorced/separated; and $12.2 \%$ among widowed). ${ }^{9}$ Moreover, married people were identified as the most risky group for HIV infection in the Uganda HIV/AIDS sero-behavioral survey. ${ }^{11}$ This difference may be caused by unawareness of their HIV status, engaging in sex with multiple partners, and their reluctance to use con- 
Table 3 Risk factors of HIV infection in Kombolcha, 2014

\begin{tabular}{|c|c|c|c|c|c|c|}
\hline \multirow[t]{2}{*}{ Variables } & \multirow[t]{2}{*}{ Category } & \multicolumn{2}{|c|}{ HIV status } & \multirow[t]{2}{*}{ COR (95\% Cl) } & \multirow[t]{2}{*}{ AOR (95\% CI) } & \multirow[t]{2}{*}{$P$-value } \\
\hline & & Negative & Positive & & & \\
\hline \multirow[t]{2}{*}{ Residence } & Urban & 309 & 23 & $2.57(1.30-5.08)$ & $2.53(1.22-5.25)$ & 0.013 \\
\hline & Rural & 484 & 14 & I & $\mathrm{I}$ & \\
\hline \multirow[t]{2}{*}{ Sex } & Male & 470 & 18 & I & I & \\
\hline & Female & 323 & 19 & I.54 (0.79-2.97) & - & - \\
\hline \multirow[t]{2}{*}{ Marital status } & Never married & 663 & 6 & I & I & \\
\hline & Married at least once & 130 & 31 & $26.4(10.8-64.4)$ & II.65 (4.2-32.3) & $<0.001$ \\
\hline \multirow[t]{2}{*}{ Age, years } & $15-29$ & 665 & 12 & I & - & - \\
\hline & $30+$ & 128 & 25 & $10.8(5.3-22.1)$ & - & - \\
\hline \multirow[t]{2}{*}{ Did the patient use alcohol/drug/Khat? } & Yes & $17 \mid$ & 13 & $1.97(0.98-3.95)$ & - & - \\
\hline & No & 622 & 24 & I & I & \\
\hline \multirow{2}{*}{$\begin{array}{l}\text { Did the patient ever have intercourse with } \\
\text { penetration? }\end{array}$} & Yes & 310 & 35 & $27.3(6.5-1 \mid 4.2)$ & 5.62 (I.II-28.57) & 0.037 \\
\hline & No & 483 & 2 & I & I & \\
\hline
\end{tabular}

Note: Hosmer and Lemeshow model fit: $X^{2}=2.314, P=0.678$. Variables having $P$-value $<0.05$ in the multivariate analysis were taken as significant association with $H I V$ infection. Abbreviations: $\mathrm{AOR}$, adjusted odds ratio; $\mathrm{Cl}$, confidence interval; $\mathrm{COR}$, crude odds ratio; $\mathrm{HIV}$, human immunodeficiency virus.

doms. Whereas, the low rate of infection among unmarried people is ascribed to their vigilance in having protected sex. ${ }^{12}$

In the present study, patients who had intercourse with penetration were more likely to contract HIV than their counterparts. Longer and rougher sex can irritate the mucous membrane thereby increasing the likelihood of viral transmission. Safe sexual behavior in which the exposure of infectious body fluids is minimized, such as intercourse using a condom, reduces risk. ${ }^{13,14}$

The limitation of this study was the lack of data for some additional variables that may have an important input to identify risk factors of HIV infection.

\section{Conclusion}

Despite the trend of HIV infection rate being significantly reduced in the last 10 years in Kombolcha area, the infection still remains high (4.5\%). Having intercourse with penetration, marriage experience, and urban resident were factors for HIV infection. Hence, this needs intervention especially in those who have risky sexual behavior, marriage experience, and are urban residents.

\section{Acknowledgments}

The authors would like to thank the management and staff of Africa Service Committee clinic, Kombolcha office, for their kind support and willingness to provide the data collected in the 10 years. This study would not have been possible without their cooperation and support.

\section{Author contributions}

MBS, GBG, MAS, and YAY designed the study, collected the data, performed the statistical analysis, and drafted the manuscript. All authors read and approved the final manuscript. All authors contributed toward data analysis, drafting and revising the paper and agree to be accountable for all aspects of the work.

\section{Disclosure}

The authors report no conflicts of interest in this work.

\section{References}

1. Sam D. Challenges of Containing New HIV Infections in Ethiopia: Unacknowledged Transmission Route. Capstone Collection. 2013. Available from: http://digitalcollections.sit.edu/capstones/2610. Accessed 5 December 2015

2. Ethiopian Public Health Institute and Federal Ministry of Health. HIV Related Estimates and Projections for Ethiopia. Addis Ababa; 2014. Available from: http://www.ephi.gov.et/images/pictures/HIV\%20 Related\%20Estimates\%20and\%20Projections\%20for\%20Ethiopia2014-National.pdf. Accessed 5 December 2015.

3. Federal HIV/AIDS Prevention and Control Office /Federal Ministry of Health. Strategic Plan II for Intensifying Multisectoral HIV and AIDS Response in Ethiopia 2010/11-2014/15. Addis Ababa, Ethiopia; 2010. Available from: http://www.nationalplanningcycles.org/sites/default/ files/country_docs/Ethiopia/aids_hiv_strategic_plan_2010-2015.pdf. Accessed 5 December 2015.

4. Berhane Y, Mekonnen Y, Seyoum E, Gelmon L, Wilson D. HIV/ AIDS in Ethiopia an Epidemiological Synthesis. Ethiopia HIV/AIDS Prevention \& Control Office (HAPCO) and Global HIV/AIDS Monitoring and Evaluation Team (GAMET). Available from: http://siteresources. worldbank.org/INTHIVAIDS/Resources/375798-1103037153392/ EthiopiaSynthesisFinal.pdf. Accessed 5 December 2015.

5. Federal HIV/AIDS Prevention and Control Office Federal Ministry of Health. HIV Prevention Package: MARPs and Vulnerable Groups, 2011. Available from: http://www.etharc.org/index.php/resources/download/ finish/33/702. Accessed 5 December 2015.

6. Ministry of Health and HAPCO. TB and HIV Concept Note, 2014.

7. Central Statistical Agency. Population and Housing Census of Ethiopia, 2007. Available from: http://www.csa.gov.et/newcsaweb/images/documents/pdf_files/regional/Amhara1.pdf.

8. Federal HIV/AIDS Prevention and Control Office (FHAPCO). Country Progress Report on the HIV Response. Addis Ababa, 2014. Available from: http://www.unaids.org/sites/default/files/country/documents/ ETH_narrative_report_2014.pdf. 
9. CSAICF International. Ethiopia Demographic and Health Survey, 2011. Addis Ababa, Ethiopia and Calverton, Maryland, USA: Central Statistical Agency and ICF International; 2012. Available from: http:// www.unicef.org/ethiopia/ET_2011_EDHS.pdf.

10. Ambert C, Jassey K, Thomas L. HIV, AIDS and urban development issues in sub-Saharan Africa. Report summary, 2007. Available from: http://www.sida.se/contentassets/b63b37325f9f473494 39bd4461486599/hiv-aids-and-urban-development-issues-in-subsaharan-africa_689.pdf.Accessed 26 February 2016.

11. Ouma F. Uganda: HIV - Govt. to Focus on Married People, 2007. Available from: http://allafrica.com/stories/200707040137.html.
12. Bauer H. To avoid HIV infection, don't get married, 2007. Available from: https://hivskeptic.wordpress.com/2007/11/page/2/. Accessed 26 February 2016.

13. Margaret G, Michael B, Gordon E. Prevention of Sexual Transmission of HIV/AIDS. Available from: http://www.bipai.org/Curriculums/HIVCurriculum/Prevention-of-Sexual-Transmission-of-HIV/AIDS.aspx. Accessed 26 February 2016.

14. Chakraborty H, Sena PK, Helmsa RW, et al. Viral burden in genital secretions determines male-to-female sexual transmission of HIV-1: a probabilistic empiric model. AIDS. 2001;15(5): $621-627$.

\section{Publish your work in this journal}

HIV/AIDS - Research and Palliative Care is an international, peerreviewed open access journal focusing on advances in research in HIV, its clinical progression and management options including antiviral treatment, palliative care and public healthcare policies to control viral spread. The journal is included in PubMed. The manuscript man- agement system is completely online and includes a very quick and fair
peer-review system, which is all easy to use. Visit http://www.dovepress. peer-review system, which is all easy to use. Visit http://www.dovepress.
com/testimonials.php to read real quotes from published authors. 